\title{
A Comparative Analysis of the Quality of Islamic and Conventional Banks' Asset Management in Indonesia
}

\author{
M. Shabri Abd. Majid, ${ }^{{ }^{*} \#}$ Said Musnadi, ${ }^{b}$ and Indra Yadi Putra ${ }^{b}$ \\ a) Department of Islamic Economics, Faculty of Economics, Syiah Kuala University, Banda Aceh, Indonesia \\ b) Department of Management, Faculty of Economics, Syiah Kuala University, Banda Aceh, Indonesia
}

\begin{abstract}
This research empirically and comparatively examines the quality of conventional and Islamic banks' asset management in Indonesia during the period 2009-2011. Four general conventional banks [i.e., Bank Mandiri Indonesia (BMI), Bank Rakyat Indonesia (BRI), Bank Central Asia (BCA), and Bank Nasional Indonesia (BNI)] and four Islamic banks (Bank Muamalat, Bank Syariah Mandiri, Bank Syariah Mega Indonesia, and Bank Syariah BRI) were, respectively, explored. Specifically, the purpose of this study is to compare the quality of the Islamic and conventional banks' asset management with the CAMEL (capital, asset, management, earning, and liquidity) method. It also attempts to analyse the influences of the $\mathrm{ROA}$ (Return on Asset), TLTA (Total Loan to Total Assets), and OITL (Operating Income to Total Liabilities) on the quality of the banks' asset management. The CAMEL method was used to evaluate the quality level of the banks' asset management, while the multiple regression analysis was then adopted to explore the determinants of the quality of the banks' asset management. The study documented that Bank Syariah BRI was the best performing bank, with the highest CAMEL score of 50.33, while Bank Mandiri Indonesia was the worst performer with the low est $C A M E L$ score of 26.33. As a group, the Islamic banks were found to have better rankings, i.e., positions 1,2, 3, and 6, while the conventional banks were found in $4,5,7$, and 8 , respectively. The study proved that the Islamic banks have a better asset management quality compared to their conventional counterparts. The Islamic banks were also proved to be better able to withstand the risks, particularly the financing risk.
\end{abstract}

Abstrak: Penelitian ini secara empiris dan komparatif meneliti kualitas manajemen aset bank konvensional dan syariah di Indonesia selama periode 2009-2011. Empat bank konvensional umum [yaitu, Bank Mandiri Indonesia (BMI), Bank Rakyat Indonesia (BRI), Bank Central Asia (BCA), dan Bank Nasional Indonesia (BNI)] dan empat bank syariah (yaitu, Bank Muamalat, Bank Syariah Mandiri, Bank Syariah Mega Indonesia, dan Bank Syariah BRI) akan dieksplorasi. Secara khusus, penelitian ini bertujuan untuk membandingkan kualitas manajemen aset bank syariah dan konvensional dengan metode CAMEL (kapital, aset, manajemen, earning, dan likuiditas). Penelitian ini juga menganalisis pengaruh profitabilitas, risiko kredit atau pinjaman dan manajemen utang terhadap tingkat kualitas manajemen aset bank. Metode CAMEL digunakan untuk mengevaluasi tingkat kualitas manajemen aset bank, sedangkan analisis regresi berganda kemudian diadopsi untuk mengeksplorasi faktor-faktor penentu kualitas manajemen aset bank. Studi ini menemukan bahwa Bank Syariah BRI adalah bank dengan tingkat kualitas manajemen aset tertinggi dengan skor CAMEL

\#The authors would like to thank the referees of the jou rnal for providing helpful com ments on the earlier draft of the paper. However, the authors bear sole responsibility for any errors.

* Corresponding author's e-mail: hannanan@gmail.com

ISSN: $1141-1128$ 
tertinggi 50,33, sedangkan Bank Mandiri Indonesia adalah bank dengan tingkat kualitas manajemen aset terendah dengan skor CAMEL terendah 26,33. Secara keseluruhan, bank syariah ditemukan memiliki peringkat kualitas manajemen aset yang lebih baik, yaitu peringkat 1, 2,3, dan 6 , sedangkan bank konvensional berada pada peringkat 4, 5, 7, dan 8 . Hasil penelitian ini menunjukkan bahwa bank syariah memiliki tingkat kualitas manajemen aset yang lebih baik dibandingkan dengan pesaingnya, bank konvensional. Bank-bank syariah juga terbukti memiliki tingkat kualitas yang lebih baik dalam mengelola risiko, terutama risiko pembiayaan.

Keywords: asset management; CAMEL; credit risk; Islamic vs. conventional banks; profitability

\section{Introduction}

The asset management of the financial services industry has long been a focus of banking research in the last few decades. The amount of attention that banking asset management research has received is understandable. Their findings have obvious implications for bank management who seek to improve asset management, efficiency, and productivity performance, and for policy makers who are concerned about banking competition and bank safety and soundness (Kwan 2003). Efficiency would also imply improved profitability, a greater amount of funds channelled in, better prices and quality of services for consumers and greater safety in terms of an improved capital buffer in absorbing risk (Berger et al. 1995). Thus, the study of banks' asset management and performance is important because the competition in the financial service industry in the era of globalization is tougher than in previous decades. Therefore, only the efficient banks, with better asset management will survive since efficiency is related to productivity and profitability. Motivated by this reason, this study intends to explore the quality of asset management of eight conventional and Islamic general banks in Indonesia. It also attempts to compare the quality of asset management of the Islamic banks with their conventional counterparts in Indonesia. Measuring and comparing the quality of the banks' as set management has become a main concern for bank customers, investors, and bankers in the finance industry. Information about the quality of asset management of the banks is one of the major considerations taken into account by bank customers in depositing their money. Meanwhile, by referring to the bank's asset management, it enables bank managers to offer better pricing, attracting greater deposits from the available surplus cash in society, and improving their profitability. Thus, knowing their quality of asset management, the bank's managers can design a proper strategy and policy to improve their competitive ability against their competitors.

Compared to the conventional banks that have dominated the banking industry in Indonesia since the late 1980s, Islamic banks are a relatively new banking system in Indonesia, with a market share of less than 5 percent in 2012. Although Indonesia is the country with the largest Muslim community in the world, the development of the Islamic banking system, which was initiated by the Majlis Ulama Indonesia (Indonesian Ulema Council) in the early 1990s has been relatively slow, compared to other Muslim countries, particularly Malaysia, that recorded a market share of 20 percent in 2010. Bank Muamalat Indonesia (BMI) was the first fully-fledged Isla mic 
bank in Indonesia. The prospects for Islamic banking in Indonesia are very promising, although BMI's assets were still relatively small (Rp.100.26 billion in 2010), it has increased to Rp135.9 billion (35.55 percent) in 2011 . Bank Indonesia (BI), the central bank of Indonesia, predicted that the growth of Islamic banks would be around 79 percent annually in the next few years.

During the last five years, the Islamic banking industry in Indonesia has recorded an average growth of 37.9 percent. The Financing to Deposit Ratio (FDR) has increased by 89.67 percent, Non Performing Financing (FDR) has been at 3.02 percent, the investment based financing achieved 34 percent growth, and the trade based financing amounted to 55 percent of the total financing. Islamic banking offices are now available in all 34 provinces in the country. Since the future of the Islamic banking industry in Indonesia cannot be isolated from their asset management, thus the present study is indeed timely to empirically explore the quality of the Islamic banks' asset management and compare it with their conventional counterparts.

As the banking sector is the backbone of the Indonesian economy and plays an important financial intermediary role, their ability to manage their assets is very critical to the stability of the Indonesian economy at large. Given the relationship between the well being of the banking sector and the growth of the economy (Rajan and Zingales 1998; Levine 1998; Levine and Zevros 1998; Cetorelli and Gambera 2001; Beck and Levine 2004), knowledge of the underlying factors that influence the financial sector's profitability is therefore essential, not only for the managers of the banks, but also for the numerous stakeholders such as the central banks, bankers associations, governments, and other financial authorities. Knowledge of these factors would also be helpful for the regulatory authorities and bank managers to formulate future policies for improving the profitability of the Indonesian banking sector.

By using a balanced bank level panel data for the period 2009-2011, this study seeks to empirically explore the quality of asset management of eight conventional and Islamic general banks in Indonesia based on the CAMEL (Capital, Asset, Management, Earning, and Liquidity) method. It also attempts to compare the quality of asset management of the conventional banks with their Islamic counterparts. Finally, the study also empirically investigates the determinants of the quality level of the banks' asset management. While there has been extensive literature examining the asset management of financial sectors in developed countries, similar empirical studies on factors that influence the asset management of financial institutions in developing economies, particularly in Indonesia, has been relatively scarce. Thus, this study tries to fill the existing gap in this area of research, particularly in Indonesia.

The rest of this study is structured as follows: the next section reviews related studies in the literature, followed by a section that outlines the empirical framework. Section 4 highlights the empirical findings. Finally, section 5 concludes the study, provides some policy recommendations, and offers avenues for future research.

\section{Selected Previous Studies}

The empirical studies on banks' asset management have mainly focused on the U.S. banking system (Berger 1987; Angbazo 1997; 
DeYoung and Rice 2004; Stiroh and Rumble 2006; Hirtle and Stiroh 2007) and the banking systems in the Western and developed countries, e.g. New Zealand (To and Tripe 2002), Australia (Williams 2003), Greece (Pasiouras and Kosmidou 2007; Kosmidou et al. 2007; Athanasoglou et al. 2008; Kosmidou and Zopounidis 2008). In contrast, few studies have looked at banks' asset management in developing economies, particularly the ASEAN economies, e.g. Malaysia (Guru et al. 2002; and Sufian 2009), Thailand (Chantapong 2005), the Philippines (Sufian and Chong 2008), and Indonesia (Swandari 2002; Almilia and Herdiningtyas 2005; Aryati and Balafif 2007; Hastuti and Subaweh 2008; Lestari 2009; and Arafat 2011).

Compared to the empirical studies on the asset management of conventional banks in Indonesia, the studies on the quality of ass et management of the Isla mic banking system have been limited. Such studies have been conducted by Rubitoh (2003), Wulandari (2004), Omar et al. (2007), and Nugraheni (2011). In her study, Rubitoh (2003) investigated the impact of economic fluctuations on Isla mic banking in Indonesia. She found that although the Islamic banks had been adversely affected by the economic cycle, the effect was relative small. On the other hand, Wulandari (2004) highlighted descriptively the comparative advantages of the first fully-fledged Islamic bank in Indonesia, Bank Muamalat Indonesia (BMI) and compared it with the conventional banks. He found that BMI had few comparative advantages compared to its conventional counterparts.

Furthermore, using a non-parametric approach, i.e., data envelopment analysis (DEA), Omar et al. (2006) studied the efficiencies of 21 private banks in Indonesia during 2002 to 2004. In their study, Omar at al. (2006) included two Islamic banks. The study documented that although the two Islamic banks, Bank Syariah Mandiri and BMI were operating above the average cost, but on average, the conventional banks were found to be more efficient than the Islamic banks. They suggested that, an improving in bank scale, technical efficiency, and pure efficiency change were the best way for the Islamic Banks to be in a better position and to gain a competitive advantages over the conventional banks.

The latest study by Veverita (2011) has also attempted to compare the quality of asset management of Islamic and conventional banks using three financial efficiency ratios (i.e. cost efficiency ratios, revenue efficiency ratios and profit efficiency ratios). She found that there was a significant asset management improvement by Islamic banks due to their costs and revenue efficiency. Compared to the conventional banks, she documented that Islamic banks experienced a lower cost efficiency, but they recorded higher revenue and profit efficiencies than those of the conventional banks. 


\section{Empirical Frameworks and Data}

\section{Empirical Framework}

This study empirically compares the quality of asset management of Islamic banks to their conventional counterparts. It also attempts to investigate the quality of asset management of the Islamic and conventional banks in Indonesia based on the regulation by the central bank of Indonesia, Bank Indonesia, No. 9/1/PBI/2007). According to the $\mathrm{BI}$ regulation, five indicators have been used to assess the asset management of the banks, i.e., Capital Adequacy (C), Asset Quality (A), bank management $(\mathrm{M})$, Earning $(\mathrm{E})$, and Liquidity $(\mathrm{L})$. In short, these five indicators are known by the acronym "CAMEL". BI has assigned the weightage for each CAMELindicator to measure the banks' asset management as shown by the following Table 1 . The description of the investigated variables is explained in the following Table 2 .

Thus, based on the CAMEL weightage, the asset management of the banks can then be calculated based on the Equation (1).

Table 1. Weightage of CAMEL

\begin{tabular}{ccc}
\hline No & CAMEL & Weightage \\
Indicator & $(\%)$ \\
\hline
\end{tabular}

1. Capital Adequacy (C) 30

2. Asset Quality (A) 30

3. Bank Management (M) 20

4. Earning (E) 10

5. Liquidity (L) 10

Source: Bank Indonesia (2007)

$$
\begin{aligned}
\mathrm{Y}= & 0.3(\mathrm{CAR})+0.3(\mathrm{NPL})+0.2(\mathrm{NPM}) \\
& +0.1(\mathrm{NIM})+0.1(\mathrm{OCOI})] / 2 \\
& +0.1(\mathrm{LDR}) \ldots \ldots \ldots \ldots \ldots \ldots \ldots \ldots \ldots \ldots \ldots \ldots \ldots \ldots \ldots \ldots \ldots \ldots
\end{aligned}
$$

where, $Y$ is the banks' asset management, NPL is a non-performing loan (or financing), $N P M$ is the net profit margin, NIM is the net interest margin, OCOI is the ratio of operating cost to operating income, and $L D R$ is the loan to deposit ratio.

Thus, to empirically compare the quality of the asset management of the Islamic and conventional banks, which was calculated based on the above Equation (1); the study uses the mean-different test based on the independent sample t-test. Furthermore, to explore the determinants of the quality of the asset management of the banks, the study regresses the asset management of the banks (Y) as the dependent variables against the dependent va riables i.e., the Return on Asset (ROA), the Total Loan to Total Asset (TLTA) and the Operating Income to Total Liabilities (OITL) with the Equation (2).

$$
\begin{aligned}
\mathrm{Y}_{\mathrm{it}}= & a+b_{1} \mathrm{ROA}_{\mathrm{it}}+b_{2} \mathrm{TLTA}_{\mathrm{it}}+b_{3} \mathrm{OITL}_{\mathrm{it}} \\
& +e_{\mathrm{it}} \ldots \ldots \ldots \ldots \ldots \ldots \ldots \ldots \ldots \ldots \ldots \ldots \ldots \ldots \ldots \ldots \ldots \ldots \ldots \ldots \ldots \ldots \ldots \ldots \ldots \ldots \ldots \ldots \ldots \ldots \ldots \ldots \ldots \ldots \ldots
\end{aligned}
$$

where: $Y_{i t}$ is the asset management of the bank $i$ for year $t$, calculated by the Equation (1), $a$ is the constant term, $b_{1}, b_{2}$, and $b_{3}$ are the estimated parameters, $R O A$ is the return on assets of the bank $i$ for year $t$, TLT $A$ is the total loan to total assets of the bank $i$ for year $t$, OITL is the operating income to total loan of the bank $i$ for year $t$, and $e$ is the error term.

It is important to note here that the commercial Islamic and conventional banks compared in the study we re categorized in the different levels of business activity by the central bank of Indonesia, Bank Indonesia. 


\section{Table 2. Operationalization of Variables}

\begin{tabular}{|c|c|c|c|}
\hline Variable & Definition & Measurement & $\begin{array}{l}\text { Previous } \\
\text { Studies }\end{array}$ \\
\hline \multicolumn{4}{|l|}{ Dependent (Y): } \\
\hline $\begin{array}{l}\text { Bank asset } \\
\text { management } \\
\text { measured by } \\
\text { CAMEL }\end{array}$ & $\begin{array}{l}\text { The ability of a bank to } \\
\text { conduct a normal banking } \\
\text { operations and its ability to } \\
\text { meet all its obligations } \\
\text { according to the regulation. }\end{array}$ & $\begin{array}{l}\mathrm{Y}=0.3(\mathrm{CAR})+0.3(\mathrm{NPL})+ \\
0.2(\mathrm{NPM}) \\
\quad+[0.1(\mathrm{NIM})+0.1(\mathrm{OCOI})] / 2 \\
\quad+0.1(\mathrm{LDR})\end{array}$ & \\
\hline \multicolumn{4}{|l|}{$\begin{array}{l}\text { CAMEL } \\
\text { Indicators: }\end{array}$} \\
\hline $\begin{array}{l}\text { Capital } \\
\text { Adequacy Ratio } \\
\text { (CAR) }\end{array}$ & $\begin{array}{l}\text { Ratio measures the amount of } \\
\text { a bank's core capital to } \\
\text { its risk-weighted asset. }\end{array}$ & $\begin{array}{c}\mathrm{CAR}=(\text { Own Capital } / \text { risk- } \\
\text { weighted Asset }) \\
\text { x } 100\end{array}$ & Yoon (2006), \\
\hline $\begin{array}{l}\text { Non-Performing } \\
\text { Loan (NPL) }\end{array}$ & $\begin{array}{l}\text { The ability of the bank to } \\
\text { manage its non-performing } \\
\text { loan. }\end{array}$ & NPL $=($ NPL/Total NPL) $\times 100$ & $\begin{array}{l}\text { Aryati and } \\
\text { Bala fif } \\
(2007)\end{array}$ \\
\hline $\begin{array}{l}\text { Net Profit } \\
\text { Margin (NPM) }\end{array}$ & $\begin{array}{l}\text { Ratio measures the net profit } \\
\text { to operating income }\end{array}$ & $\begin{array}{c}\text { NPM }=\text { (Net Profit/Operating } \\
\text { Income) } \\
\times 100\end{array}$ & $\begin{array}{l}\text { Lestari } \\
(2009) ; \\
\text { Hastuti and } \\
\text { Subaweh }\end{array}$ \\
\hline $\begin{array}{l}\text { Net Interest } \\
\text { Margin (NIM) }\end{array}$ & $\begin{array}{l}\text { Measuring the difference } \\
\text { between the interest income } \\
\text { relative to the amount of their } \\
\text { interest-earning assets. }\end{array}$ & $\begin{array}{c}\text { NIM }=(\text { Net Interest Income/ } \\
\text { Productive Assets }) \text { x } 100\end{array}$ & $\begin{array}{l}\text { Swandari } \\
\text { (2002) }\end{array}$ \\
\hline $\begin{array}{l}\text { Operating Cost } \\
\text { to Operating } \\
\text { Income }(\mathrm{OCOI})\end{array}$ & $\begin{array}{l}\text { Ratio measures the operating } \\
\text { cost to the operating income }\end{array}$ & $\begin{array}{c}\text { OCOI }=(\text { Operating Cost } / \\
\text { Operating } \\
\text { Income }) \times 100\end{array}$ & \\
\hline $\begin{array}{l}\text { Loan to Deposit } \\
\text { Ratio (LDR) }\end{array}$ & $\begin{array}{l}\text { Ratio measures bank's } \\
\text { liquidity by dividing the } \\
\text { financial institution's total } \\
\text { loans by its total depo sits. }\end{array}$ & $\mathrm{LDR}=($ Loan/Deposit $) \times 100$ & \\
\hline Independent: & & & $\begin{array}{l}\text { Lestari } \\
(2009)\end{array}$ \\
\hline Profitability & $\begin{array}{l}\text { Measuring the ability of the } \\
\text { banks to generate profit using } \\
\text { its available total assets. }\end{array}$ & $\begin{array}{l}\text { ROA }=(\text { Net Income after } \\
\text { tax/Total assets }) \times 100\end{array}$ & $\begin{array}{l}\text { Hastuti and } \\
\text { Subaweh } \\
\text { (2008); } \\
\text { Samad (2004) }\end{array}$ \\
\hline Credit Risk & $\begin{array}{l}\text { The risk of loss of principal } \\
\text { stemming from a borrower's } \\
\text { failure to repay a loan or } \\
\text { otherwise meet a contractual } \\
\text { obligation. It measured by the } \\
\text { total common equity to total } \\
\text { assets. }\end{array}$ & $\begin{array}{c}\text { TLTA }=(\text { Total Loan } / \text { Total } \\
\text { Assets }) \times 100\end{array}$ & Samad (2004) \\
\hline $\begin{array}{l}\text { Debt } \\
\text { Management }\end{array}$ & $\begin{array}{l}\text { The ability of bank to have } \\
\text { enough cash flow to cover } \\
\text { debt obligations }\end{array}$ & $\begin{array}{c}\text { OITL }=(\text { Net Operating } \\
\text { Income/Total Liabilities }) \times 100\end{array}$ & $\begin{array}{l}\text { Swandari } \\
(2002)\end{array}$ \\
\hline
\end{tabular}


Since 2013, Bank Indonesia has categorized the commercial banks in the country into four levels of the business activity based on their core capital and offices' networks (Chapter No. 1, Article No.1 of the central bank of Indonesia's regulation, No. 15/11/PBI/ 2013). Based on the regulation, the investigated Islamic and conventional banks in the study were categorized in the levels 4 and 2 of the business activity, respectively. Thus, the findings of the study should be interpreted cautiously. In interpreting the findings of this study, the following assumptions were made pertaining to the Islamic banks: they have limited: (i) market share, (ii) business exposure, (iii) depositors and business partners, (iv) international market access, and (iv) levels of operations and risk pressure, compared to their conventional counterparts.

\section{Data}

This study empirically compares the levels of the bank's asset management between the conventional and Islamic banks based on the CAMEL method during the period 2009 to 2011. Annual data of the four Islamic and conventional banks' financial ratios respectively was used in the analysis. The data of the financial ratios used in this study have many advantages. The most important benefit of the use of the ratio method is that it compensates bank disparities (Samad 2004: 6, and Hazzi and Al Kilani 2013). The investigated Islamic and conventional banking firms, which were categorized in the levels 4 and 2 of banking business activity respectively (see central bank of Indonesia regulation, No. 15/11/PBI/2013) will be not equal with respect to their sizes. The use of the ratio should remove the disparities in size and bring them at a par. In addition, the study decided to compare the banks with different levels of banking business activity

Meanwhile, the selected banks that were investigated in this study are shown in Table 3, which are based on their similar assets' characteristics and data availability.

The secondary data used in the study was collected from various sources including Bank Indonesia (www.bi.go.id), Yahoo Finance (http:// finance.yahoo.com), Daily Balance (www.neraca.co.id), Business News (www.bisnis.com), Magazine Info Bank (www. infobank.com), and the reports from each bank, which were published on their respective websites.

Table 3. List of Investigated Banks

\begin{tabular}{lll}
\hline No. & Conventional Bank & \multicolumn{1}{c}{ Islamic Bank } \\
\hline 1. & Bank Mandiri Indonesia & Bank Syariah Muamalat \\
2. & BRI Persero Tbk & Bank Syariah Mandiri \\
3. & Bank Central Asia Tbk & Bank Syariah Mega Indonesia \\
4. & BNI Persero, Tbk & Bank Syariah BRI \\
\hline
\end{tabular}




\section{Findings and Discussions}

\section{The Asset Management of the Banks}

Table 4 reports the quality level of the asset management of the banks according to the CAMEL score, which was calculated based on the Equation (1). Table 4 recorded that the Islamic banks generally have higher levels of $C A M E L$ score as compared to their conventional counterparts, indicating that the Islamic banks have a better quality of asset management than the conventional banks. The Isla mic banks were ranked $1^{\text {st }}, 2^{\text {nd }}$, $3^{\text {td }}$ and $6^{\text {th }}$, while the conventional banks were, respectively, ranked in the $4^{\text {th }}, 5^{\text {th }}, 7^{\text {th }}$ and $8^{\text {th }}$. On the average, the CAMEL score for the Islamic banks (35.42) was higher than the conventional banks (27.75) during 20092011.

Table 4 also showed that, overall the Isla mic banks have improved their quality of asset management faster than the conventional banks have. The conventional banks have decreased their quality level of asset management by 0.50 percent from 2009 to 2010 , increased to 1 percent in 2011 . On the other hand, the Islamic banks only recorded a decline in their quality level of asset management by 1 percent from 2009 to 2010 , but have sharply increased by 3.25 percent in 2011. These findings proved that the Isla mic banks have a better growth in their asset management as compared to the conventional banks.

Tabel 4. The Level of Bank's Asset Management Based on the CAMEL Score

\begin{tabular}{|c|c|c|c|c|c|c|}
\hline \multirow[b]{2}{*}{ No } & \multirow[b]{2}{*}{ Bank } & \multicolumn{4}{|c|}{ CAMEL Score } & \multirow[b]{2}{*}{ Bank's Type } \\
\hline & & 2009 & 2010 & 2011 & Mean & \\
\hline 1. & Bank Syariah BRI & 50 & 44 & 57 & 50.33 & Islamic \\
\hline 2. & Bank Syariah Mega Indonesia & 31 & 32 & 34 & 32.33 & Islamic \\
\hline 3. & Bank Syariah Muamalat & 31 & 32 & 30 & 31.00 & Islamic \\
\hline 4. & BRI Persero Tbk & 30 & 29 & 30 & 29.66 & Conventional \\
\hline 5. & BNI Persero, Tbk & 29 & 28 & 29 & 28.66 & Conventional \\
\hline 6. & Bank Syariah Mandiri & 28 & 28 & 28 & 28.00 & Islamic \\
\hline 7. & Bank Central Asia Tbk & 27 & 26 & 26 & 26.33 & Conventional \\
\hline \multirow[t]{3}{*}{8.} & Bank Mandiri Indonesia & 25 & 26 & 28 & 26.33 & Conventional \\
\hline & Mean & 27.75 & 27.25 & 28.25 & 27.75 & Conventional \\
\hline & Mean & 35.00 & 34.00 & 37.25 & 35.42 & Islamic \\
\hline
\end{tabular}


Table 5. Des criptive Statistics

\begin{tabular}{lcccc}
\hline Variable & Minimum & Maximum & Mean & Standard Dev. \\
\hline \multicolumn{2}{l}{ Conventional Bank } & & & \\
CAMEL & 25.50 & 35.00 & 27.75 & 2.07 \\
ROA & 1.57 & 4.93 & 9.37 & 0.75 \\
TLTA & 6.00 & 14.00 & 53.39 & 1.61 \\
OITL & 26.00 & 100.00 & 31.35 & 18.65 \\
Islamic Bank & & & & \\
CAMEL & -2.00 & 123.00 & 35.42 & 16.40 \\
ROA & 0.20 & 3.18 & 1.58 & 0.81 \\
TLTA & 7.00 & 30.00 & 10.66 & 4.92 \\
OITL & -1.00 & 27.00 & 12.56 & 7.44 \\
\hline
\end{tabular}

\section{Descriptive Statistics}

Table 5 shows the descriptive statistics of the investigated variables. Table 5 portrayed that the CAMEL score for the conventional banks had a minimum value of 25.50 , a highest value of 35.00 , the average value of 27.75 , and a standard deviation of 2.07. Compared to the conventional banks, the Islamic banks recorded the lowest CAMEL score of -2.00. Meanwhile, the minimum and maximum ratios of $\mathrm{RO} A$ were respectively 0.20 and 4.93 , with the average of 2.42 and a standard deviation of 1.15. TLT $A$ variable has a minimum value of 6.00 , a maximum value of 30.00 , the average value of 10.02 and a standard deviation of 3.70 . Finally, the OITL variable has a minimum value of -1.00 , the maximum value of 100.00 , the average of 32.97 , and a standard deviation of 24.91 .

\section{Coefficients of Correlation}

Table 6 reports the correlation among the dependent and independent variables. As for the conventional banks, there was a very weak correlation between the CAMEL score and TLT $A$, and weak correlation between the TLT $A$ and OITL at the significant level of 5 percent, respectively. Meanwhile, there were also weak correlations between the CAMEL score and TLTA, CAMEL score and OITL, and between the ROA and OITL at least at the 1 percent significance level. 
Table 6. Pearson-Coefficients of Correlation

\begin{tabular}{lllll}
\hline Coefficient & CAMEL & ROA & TLTA & OITL \\
\hline
\end{tabular}

Conventional Banks

CAMEL

1.00

ROA

0.08

1.00

TLTA

$0.29 *$

$-0.19$

1.00

OITL

$-0.20$

0.08

$0.26 *$

1.00

Islamic Banks

CAMEL

1.00

ROA

$0.31 *$

1.00

TLTA

$0.35 * *$

$-0.09$

1.00

OITL

$-0.35 * *$

$0.71 * *$

$-0.11$

1.00

Note: $* *$ and ${ }^{*}$ indicating significant at 1 percent and 5 percent levels, respectively.

\section{Differences in Quality of Asset Management between the Islamic and Conventional Banks}

Tables 7 and Table 8 report the results of a comparison between the mean of the quality of the asset management of the Islamic banks to their conventional counterparts, based on the independent sample t-test. Table 7 documented that the Islamic banks had recorded a higher mean of the quality of the asset management (performed better) with a value of 39.56 than the conventional banks (31.35). This difference was significant at the level of 1 percent, as shown by the t-test for equality means and the Levene's test for equality of variances (Table 8). This finding supported our earlier findings which showed that the Islamic banks have a better asset management system compared to their conventional counterparts. This is simply due to the differences in Islamic banks, which have: (i) limited market share; (ii) limited levels of operations and risk; (iii) limited business exposure, (iii) limited depositors and business partners; and (iv) limited international market access. If in the future, the Islamic banks have similar conditions to their conventional counterparts, the scenario and results of the study might be different. In addition, the ability of Islamic banks to manage their limited risk compared to their conventional counterparts is believed to contribute to these differences. 
Table 7. Group Statistics $(n=48)$

\begin{tabular}{llccc}
\hline & Bank & Mean & Std. Deviation & Std. Error Mean \\
\hline CAMEL & Conventional & 27.750 & 2.078 & 0.299 \\
& Islamic & 35.420 & 16.409 & 2.368 \\
\hline
\end{tabular}

Table 8. Independent Sample Test

\begin{tabular}{|c|c|c|c|c|c|c|c|c|}
\hline & & \multicolumn{2}{|c|}{$\begin{array}{c}\text { Levene's } \\
\text { Test for } \\
\text { Equality of } \\
\text { Variances }\end{array}$} & \multicolumn{5}{|c|}{ t-test for Equality of Means } \\
\hline & & $\mathbf{F}$ & Sig. & $\mathbf{t}$ & df & Sig. & $\begin{array}{l}\text { Lower } \\
\text { (2-tailed) }\end{array}$ & Upper \\
\hline \multirow[t]{2}{*}{ CAMEL } & $\begin{array}{l}\text { Equal variances } \\
\text { assumed }\end{array}$ & $15.952^{*}$ & 0.000 & -3.438 & 94.00 & $0.001^{*}$ & -12.948 & -3.468 \\
\hline & $\begin{array}{l}\text { Equal variances } \\
\text { not assumed }\end{array}$ & & & -3.438 & 48.507 & $0.001^{*}$ & -13.007 & -3.409 \\
\hline
\end{tabular}

Note: $* *$ indicating significant at 1 percent level.

\section{Determinants of the Quality of Banks' Asset Management}

A multiple linear regression was performed to determine the extent to which the independent variables, namely the $R O A$, TLT $A$, and OITL affect the dependent variable, the quality of the asset management of the banks. Tests were performed twice; the first test was conducted to measure the determinants of the quality of the asset management of the conventional banks, while the second test was meant to explore the determinants of the quality of the Islamic banks asset management.

Based on the Table 9, the estimated equations for each bank can be formulated as follows:
For conventional banks:

$$
\begin{aligned}
& \mathrm{Y}_{\mathrm{it}}=26.60^{* *}+0.51 \mathrm{ROA}_{\mathrm{it}}+0.53 \mathrm{TLTA}_{\mathrm{it}}{ }^{*} \\
& \text { (11.75) (1.35) } \\
& -0,37 \text { OITL }_{\text {it }}^{*} \\
& (-2.33)
\end{aligned}
$$

For Islamic banks:

$$
\begin{aligned}
& \mathrm{Y}_{\mathrm{it}}=38.48^{* *}-2.29 \mathrm{ROA}_{\mathrm{it}}+1.06 \mathrm{TLTA}^{*}{ }_{\mathrm{it}} \\
& \text { (5.45) } \quad(-0.60) \\
& -0,52 \text { OITL }_{\text {it }} \\
& (-1.27)
\end{aligned}
$$

Note: Figure in parentheses (.) show the t-value; ${ }^{*}$ and ${ }^{*}$ indicating significant at 1 percent and 5 percent levels, respectively.

Referring to Table 9 and the two-estimated linear equations, the study found that 
Table 9. Results of Multiple Regressions

\begin{tabular}{|c|c|c|c|c|}
\hline \multirow[b]{2}{*}{ Model } & \multicolumn{4}{|c|}{ Conventional Banks } \\
\hline & $\begin{array}{l}\text { Estimated } \\
\text { Parameter }\end{array}$ & Std. Error & $t$-value & $p$-value \\
\hline Constant & $26.60^{* *}$ & 2.26 & 11.75 & 0.00 \\
\hline ROA & 0.51 & 0.38 & 1.35 & 0.18 \\
\hline TLTA & $0.53^{* *}$ & 0.18 & 2.91 & 0.00 \\
\hline \multirow[t]{4}{*}{ OITL } & $-0.37^{*}$ & 0.01 & -2.33 & 0.02 \\
\hline & \multirow{2}{*}{\multicolumn{4}{|c|}{$\begin{array}{l}\text { F-stats }=18.98(\mathrm{p} \text {-value }=0.00) ; \mathrm{D}-\mathrm{W}=2.005 ; \\
\text { Skewness }=2.21 ; \text { Kurtosis }=0.03 ; \text { Adj- } \mathrm{R}^{2}=19.65\end{array}$}} \\
\hline & & & & \\
\hline & \multicolumn{4}{|c|}{ Islamic Banks } \\
\hline Constant & $38.48^{* *}$ & 7.06 & 5.45 & 0.00 \\
\hline ROA & -2.29 & 3.78 & -0.60 & 0.54 \\
\hline TLTA & $1.06^{*}$ & 0.44 & 2.40 & 0.02 \\
\hline \multirow[t]{2}{*}{ OITL } & -0.52 & 0.41 & -1.27 & 0.21 \\
\hline & \multicolumn{4}{|c|}{ F-stats $=23.98(\mathrm{p}$-value $=0.00) ; \mathrm{D}-\mathrm{W}=2.12$} \\
\hline
\end{tabular}

Note: ${ }^{* *}$ and ${ }^{*}$ indicating significant at 1 percent and 5 percent levels, respectively, and D-W is DurbinWatson test for autocorrelation.

the $R O A$ has an insignificant effect on the quality of the banks' asset management. This finding is consistent with the study by Hastuti and Subaweh (2008) and Almilia and Herdiningtyas (2005), implying that the $R O A$ cannot be used to predict the soundness of the banks, both Islamic and conventional.

Meanwhile, the TLTA was found to have a positive and significant effect on the quality of the asset management of both Islamic and conventional banks at the 1 percent and 5 percent levels of significance, respectively. This finding indicates that the fluctuations in the TLT $A$ affected the quality of the asset management of both banks. Statis- tically, the finding showed that any 1 percent increase (decrease) in TLT $A$ affected an increase (decrease) in the CAMEL score of 1.15 percent. To improve the quality of the asset management of the banks, the bank manager should manage the financial ratio of the TLTA. This empirical evidence further implies that the greater the percentage of the bank's capital invested into assets will increase the CAMEL scores value, because it will minimize the risk of loss of capital when compared with its placement in credit schemes. Our finding supported the earlier study by Samad (2004). 
Finally, as for the OITL effect on the quality of the banks' asset management, the study only found a negative and significant value for the conventional banks, but a dissimilar finding was recorded for the Islamic banks. This shows that the quality of the asset management of the conventional banks was adversely affected by the OITL, while the Islamic banks quality was independent of the OITL. This finding is in harmony with the study conducted by Swandari (2002).

Overall, the study found that 19.65 percent of the variability observed in quality of the asset management of the conventional banks can be explained by assessed values of the independent variables, while the variability observed in the quality of the asset management of the Islamic banks can only be explained about 11.76 percent by the independent variables, as shown by their adjusted- $R^{2}$. Thus, the assessed value of the independent variables contributes a small number of information about the quality of the asset management of both banks.

\section{Conclusion and Implications}

This study empirically examined the quality of the asset management of eight banks in Indonesia (four conventional banks i.e., Bank Mandiri Indonesia, BRI Persero Tbk, Bank Central Asia Tbk, BNI Persero Tbk; and four Islamic banks i.e., Bank Syariah Muamalat, Bank Syariah Mandiri, Bank Syariah Mega Indonesia and Bank Syariah BRI) for three consecutive years, 2009-2011. It also attempted to explore the determinants of the quality of the asset management of both Islamic and conventional banks.

The study recorded that the Islamic banks ranked higher (ranking 1, 2, 3 and 6) than the conventional banks (ranking 4, 5, 7 and 8). Overall, this implies that the Islamic banks performed better than their conventional counterparts. It was also statistically proved that the Islamic banks have a significant mean-difference compared to the mean asset management of the conventional banks, as shown by the independent sample t-test and the Levene's test for equality of variances. The limited market share, limited levels of operation and risk, limited business exposure, limited depositors and business partners, and limited international market access of the Islamic banks as opposed to their conventional counterparts contributed to the higher quality level of the Islamic banks' asset management. If the Islamic banks operate in similar conditions as their conventional counterparts in the future, the findings of the study might be different. In addition, the ability of Isla mic banks to manage their limited risk compared to their conventional counterparts is believed to contribute to these differences. This empirical evidence proved that it is indeed timely for the bank's costumers, businesses and the government to make the Islamic banks become their banks of choice either to deposit their money or to borrow money from, as well as to promote the economic growth of the country. The govemment should encourage the growth of Islamic banks and place their money there. The government, through Bank Indonesia should also recommend the existing conventional banks consider conversion to operations based on the Islamic principles.

As for the determinants of the quality of the banks' asset management, the study documented that the $\mathrm{ROA}$ was found to have an insignificant effect on the banks' asset management, implying that the $\mathrm{ROA}$ cannot be used to predict the soundness of the banks, both Islamic and conventional. Meanwhile, the TLTA was found to have a posi- 
tive and significant effect on the quality of asset management of both Islamic and conventional banks, suggesting that to enhance the soundness of the banks, the bank manager should take great care with its credit risk. This empirical evidence further implies that the greater the percentage of the bank's capital invested into assets will give an increase in the value of the CAMEL scores because it will minimize the risk of loss of capital when compared with its placement on credit. Finally, as for the OITL effect on the quality of the banks' asset management, the study only found a negative and significant value for the conventional banks, but dissimilar findings were recorded for the Islamic banks. This shows that the quality of the asset management of the conventional banks was adversely affected by the ability of the bank manager to manage the debts of the banks, while the quality of the asset management of the Islamic banks was independence of the debt management (OITL). Overall, the study found that the variability observed in the quality of the asset management of the conventional and Islamic banks could be explained about 19.65 and 11.76 percent by the assessed values of the independent variables, respectively.

The findings and implications of this study are limited to the selected investigated banks during the period 2009-2011 in Indonesia. Incorporating a longer sample period, covering more Islamic and conventional banks, and including more variables that may potentially affect the quality of the asset management of the banks might enhance further analysis and implications of the study on this issue.

\section{References}

Almilia, L.S., and W. Herdiningtyas 2005. Analisis rasio CAMEL terhadap prediksi kondisi bermasalah pada lembaga perbankan periode 2000-2002. Jurnal Akuntansi dan Keuangan 7 (2): 1411-1428.

Angbazo, L. 1997. Commercial bank net interest margins, default risk, interest rate risk, and off balance sheet banking. Journal of Banking and Finance 21 (1): 55-87.

Arafat, M. Y., A. D. Buchdadi, and Suherman. 2011. Analysis of bank's performance and efficiency in Indonesia. Social Science Research Network. Available at SSRN: http:/ / ssrn.com/abstract=1805529.

Aryati, T., and S. Balafif. 2007. Analisis faktor yang mempengaruhi tingkat kesehatan bank dengan regresi Logit. Journal The Winners 8 (2): 111-125.

Athanasoglou, P. P., S. N. Brissimis, and M. D. Delis. 2008. Bank specific, industry specific and macroeconomic determinants of bank profitability. Journal of International Financial Markets, Institutions and Money 18 (2): 121-136.

Bank Indonesia (BI). 2007. Regulation No. 9/1/ PBI/2007: The Rating System For Commercial Banks Based on Sharia Principles. Jakarta, Indonesia.

Beck, T., and R. Levine. 2004. Stock markets, banks, and growth: Panel evidence. Journal of Banking and Finance 28 (3): 423-442.

Berger, A. N. 1995. The relationship between capital and earnings in banking. Journal of Money, Credit and Banking 27 (2): 432-456.

Berger, A. N., G. A. Hanweck, and D. B. Humphrey. 1987. Competitive viability in banking: Scale scope and product mix economies. Journal of Monetary Economics 20 (3): 501-520. 
Cetorelli, N., and M. Gambera. 2001. Banking market structure, financial dependence and grow th: International evidence from industry data. Journal of Finance 56 (2): 617-648.

Chantapong, S. 2005. Comparative study of domestic and foreign bank performance in Thailand: The regression analysis Economic Change and Restructuring 38 (1): 63-83.

DeYoung, R., and T. Rice. 2004. Non-interest income and financial performance at US commercial banks. Financial Review 39 (1): 101-27.

Guru, B. K., J. Staunton, and B. Balashanmugam. 2002. Determinants of commercial bank profitability in Malaysia. Working Paper. Multimedia University, Malaysia.

Hastuti, H., and I. Subaw eh. 2008. Analisis kinerja kesehatan bank sebelum dan setelah arsitektur perbankkan Indonesia. Working Paper. Jurusan Akuntansi Fakultas Ekonomi Universitas Gunadarma.

Hazzi, O. A., and M. I. Al-Kalani. 2013. The financial performance analysis of Islamic and traditional banks: Evidence from Malaysia. European Journal of Economics, Finance and Administrative Sciences 57:133144.

Hirtle, B. J., and K. J. Stiroh. 2007. The return to retail and the performance of US banks Journal of Banking and Finance 31 (4): 1101-33.

Kosmidou, K., F. Pasiouras, and A. Tsaklanganos. 2007. Domestic and multinational determinants of foreign bank profits: The case of greek banks operating abroad. Journal of Multinational Financial Management 17 (1): 1-15.

Kosmidou, K., and C. Zopounidis 2008. Measurement of bank performance in Greece. South Eastern Europe Journal of Economics 1: 79-95.

Kwan, S. H., 2003. Operating performance of banks among Asian economies: An international and time series comparison. Journal of Banking and Finance 27 (3): 471-489.

Lestari, V. D. 2009. Analisis tingkat kesehatan bank-bank pemerintah dengan menggunakan metode CAMEL dan analisis diskriminan periode 2006-2008. Skripsi. Universitas Gunadarma, Indonesia.

Levine, R. 1998. The legal environment, banks, and long run economic grow th. Journal of Money, Credit and Banking 30 (3): 596-613.

Levine, R., and S. Zevros. 1998. Stock markets, banks, and economic grow th. American Economic Review 88 (3): 537-58.

Nugraheni, S.R.W. 2011. Analisis Daya Tahan Perbankan Syariah Terhadap Fluktuasi Ekonomi di Indonesia. Skripsi. Institut Pertanian Bogor, Indonesia.

Pasiouras, F., and K. Kosmidou. 2007. Factors influencing the profitability of domestic and foreign commercial banks in the European Union. Research in International Business and Finance 21 (2): 222 37.

Rajan, R. G., and L. Zingales 1998. Financial dependence and grow th. American Economic Review 88 (3): 559-86.

Rubitoh. 2003. Penelitian perbandingan kinerja keuangan bank muamalat dengan bank konvesional (enam bank konvensional). Skripsi. Universitas Islam Indonesia.

Samad, A. 2004. Performance of interest-free Islamic bank vis-à-vis unterest based conventional bank of Bahrain. IIUM Journal of Economics and Management 12 (2): 115-129.

Stiroh, K. J., and A. Rumble. 2006. The dark side of diversification: The case of US financial holding companies. Journal of Banking and Finance 30 (8): 2131-61. 
Sufian, F. 2009. Factors influencing bank profitability in a developing economy: Empirical evidence from Malaysia. Global Business Review 10 (2): 225-41.

Sufian, F, and R. R. Chong. 2008. Determinants of bank profitability in a developing economy: Empirical evidence from the Phillipines Asian Academy of Management Journal of Accounting and Finance 4 (2): $91-$ 112.

Swandari, F. 2002. Pengaruh perilaku risiko, kepemilikan institusi dan kinerja terhadap kebangkrutan bank umum di Indonesia. Jurnal Ekonomi dan Bisnis Indonesia 17 (4): 1-25.

To, M. H., and D. Tripe. 2002. Factors influencing the performance of foreign ow ned banks in New Zealand. Journal of International Financial Markets, Institutions and Money 12 (4-5):341-57.

Veverita. 2011. Performance analysis of Indonesian Islamic and conventional banks. Social Science Research Network. Available at SSRN: http:/ / ssrn.com/abstract=1868938.

Williams, B. 2003. Domestic and international determinants of bank profits: Foreign banks in Australia. Journal of Banking and Finance 27 (6): 1185-210.

Wulandari, N. 2004. Keunggulan komparatif bank syariah. Suara Merdeka. Indonesia.

Yoon, I-H. 2006. Financial statement analysis for differentiating between failed and surviving merchant banks. Institute of East and West Studies, Yonsei University (Institute of East and West Studies) 18 (2): 131160. 
